\title{
〔38 39〕主鎖中に芳香環を有するポリアミドの合成
}

第 1 報 脂肪族混合ジアミンとテレフタル酸ジメチルとの

ポリアミドの合成条件の検討

(1965 年 9 月 20 日受理)

後 藤 芳 弘*

\begin{abstract}
要 旨 エチレンと塩化シアンのテロメリゼーション反応により生成するテロマーの誘導体である脂肪 族混合ジアミンと, テレフタル酸ジメチルとからメタノール中でプレポリマーを合成し, さらに溶融重縮合を 行ない, 融点 $225 \sim 235^{\circ} \mathrm{C}$ の溶融紡糸可能な新しいポリアミドを得た。可紡性良好なポリマーを得るために重 合条件を検㐿した。得られたポリマーの溶解性はポリカプロアミド(ナイロン6) とポリエチレンテレフタレー トの中間にある。また, 溶融紡糸によって得られた瀻維のヤング率は, 予期したとおりポリカプロアミドより はるかに高い值を示した。
\end{abstract}

\section{1. 緒言}

ナイロン 6 , ナイロン 66 などの脂肪族ポリアミドは ヤング率が低く弾性に富み, これが利点であり,また, 久 点ともなっている。ポリアミドのヤング率向上のため, 従来からベンゼン環( ${ }^{1)}$ やピリジン環5) などを導入する 試みがなされている。

テロメリゼーション反応では単一物質が得られず, 混 合物となる。その分離, あるいは各成分の完全利用が困 難なため，その寒用化がさまたげられている。

著者らは, エチレンと塩化シアンのテロメリゼーショ ン反応により，生成するテロマーの誘導体である脂肪族 混合ジアミンを用いて，テレフタル酸やアジピン酸など の二塩基酸とから可紡性良好なポリアミドを得だ)。テ レフタル酸とポリメチレンジアミンとからのナイロン塩 は熱安定性が悪く, 溶融重縮合ではポリマーが得られな いと秋吉ら》は報告しているが，混合ジアミンの場合に はテレフタル酸とのナイロン塩にかかわらず, 重合条件 を厳密に選ぶことによって良好なポリマーを得ることが できた。しかし，ナイロン塩生成時の等量性, 重合時の ゲル化の問題があるため,ナイロン塩を経由せずに重合 することを試みた。

本報告ではテレフタル酸ジメチル (以下 DMT と略 す) と脂肪族混合湆アミン（以下 MED と略す）とから メタノール中で前段重合を行ない，プレポリマーを合成 し, さらに溶融重縮合を行ない, 可紡性良好なポリマー (MED-T ポリアミドと記す) を得た。ここでは, 前段 重合したプレポリマーの溶融重縮合に及ぽす MED と DMT とのモルバランス, 重合時間などについて検討を 行ない，それらの結果から最適の重合条件を選び，良好

* 東洋紡績株式会社瀻維技術研究所 (滋賀県滋賀郡堅田町本堅 田)

現在：東洋紡績株式会社犬山工場 (愛知県犬山市大字木津)
なポリマーを合成し，簡単な紡系実験を行なったので， あわせてその結果を報告する。

\section{2. 実験}

2.1 試 料

2.1.1 脂肪族混合ジアミン (MED)

エチレンと塩化シアンのテロメリゼーション反応によ り，得られたテロマーを下に示すよらなルートで粗成混 合ジアミンを合成し, 大科式精密蒸留装置にて減圧蒸留 し, $n=1$, 抢よび $n \geqq 6$ の留分を裹却し, bp $82 \sim 153^{\circ} \mathrm{C} /$ $10 \mathrm{mmHg}$ の留分を用いた。

$$
\begin{aligned}
n \mathrm{CH}_{2}=\mathrm{CH}_{2}+\mathrm{ClCN} \longrightarrow \mathrm{Cl}\left(\mathrm{CH}_{2} \mathrm{CH}_{2}\right)_{n} \mathrm{CN} \\
\mathrm{Cl}\left(\mathrm{CH}_{2} \mathrm{CH}_{2}\right)_{n} \mathrm{CN}+\mathrm{NaCN} \\
\longrightarrow \mathrm{NC}\left(\mathrm{CH}_{2} \mathrm{CH}_{2}\right)_{n} \mathrm{CN} \\
\mathrm{NC}\left(\mathrm{CH}_{2} \mathrm{CH}_{2}\right)_{n} \mathrm{CN}+4 \mathrm{H}_{2} \\
\longrightarrow \mathrm{NH}_{2}\left(\mathrm{CH}_{2}\right)_{2 n+2} \mathrm{NH}_{2}
\end{aligned}
$$

MED の平均メチレン鎖長 $(2 n+2)$ は $8.5 \sim 8.9$ である。 MED の分析は下記の方法で行なった。全アミンは MED 0.3 0.4 g を精科し, 約 $60 \mathrm{~m} l$ のメタノールに 溶解し， $N / 2-\mathrm{HCl}$ にて電位差滴定を行なった。

第二級アミンは MED 約 $3.5 \mathrm{~g}$ を精秤し, $150 \mathrm{ml}$ の メチルセルンルブに溶解し， $7 \mathrm{ml}$ のサルチルアルデヒ ド (市販特級) を加え， 30 分間室温でかきまぜ，N/10$\mathrm{HClO}_{4}$ のジオキサン溶液にて電遒度滴定を行なった。 通常, 2 個の当量点が認められ, 第 1 当量点を第二級ア ミンとする。

MED の分析值掞よび組成の一例を Table 1 に示す。 この実験に用いた MED はすべて,この組成に近いも のである。

2.1.2 テレフタル酸ジメチル (DMT)

丸善石油化学製のポリエステル製造用のものを $50^{\circ} \mathrm{C}$ 
Table 1. Analysis of mixed aliphatic diamines (MED).

\begin{tabular}{c|c|c|c|c}
\hline \hline MED No. & Total amine (millieq./g) & Sec. amine ${ }^{\text {a) }}$ (millieq./g) & Average molecular weight & Average $(2 n+2)$ \\
\hline D-10* & 13.06 & $1.50 \times 10^{-2}$ & 153.14 & 8.63 \\
D-22 & 13.22 & $3.56 \times 10^{-2}$ & 151.28 & 8.53 \\
D-24 & 12.82 & $0.74 \times 10^{-2}$ & 156.01 & 8.84 \\
D-36 & 12.92 & - & 154.80 & 8.75 \\
\hline
\end{tabular}

* Composition of D-10: $20 \mathrm{wt} \%$ of hexamethylenediamine, $32 \mathrm{wt} \%$ of octamethylenediamine, $29 \mathrm{wt} \%$ of decamethylenediamine and $19 \mathrm{wt} \%$ of dodecamethylenediamine. Analysis of composition was determined by the weight of fractional distillate.

a) Sec. amine : Secondary amine

Table 2. Preparations of prepolymers.

\begin{tabular}{c|c|c|c|c|c|c}
\hline \hline $\begin{array}{c}\text { Expt. } \\
\text { No. }\end{array}$ & $\begin{array}{c}\text { MED } \\
(\mathrm{g})\end{array}$ & $\begin{array}{c}\text { DMT } \\
(\mathrm{g})\end{array}$ & $\begin{array}{c}\text { Molar ratio of } \\
\text { MED/DMT }\end{array}$ & $\begin{array}{c}\text { Methanol } \\
(\mathrm{m} l)\end{array}$ & \multicolumn{3}{|c}{ Prepolymer } \\
\hline PM-31 & 29.60 & 37.99 & 1.00 & 680 & $196 \sim 205$ & $\mathrm{mp}\left({ }^{\circ} \mathrm{C}\right)$ \\
PM-32 & 35.26 & 43.10 & 1.05 & 750 & $198 \sim 210$ & 8.81 \\
PM-33 & 31.89 & 37.21 & 1.10 & 680 & $191 \sim 206$ & 9.37 \\
PM-34 & 36.12 & 40.31 & 1.15 & 750 & $195 \sim 205$ & 10.15 \\
PM-35 & 31.84 & 32.69 & 1.25 & 630 & $200 \sim 213$ & 10.27 \\
\hline
\end{tabular}

a) D-22 of Table 1, b) DMT: Dimethyl terephthalate

で減圧乾燥して用いた。

\subsection{3 ヘキサメチレンジアミン (HMD)}

市販のへキサメチレンジアミンを粒状 $\mathrm{KOH}$ で乾燥 し, 窒素気流中で 2 回精留を行なって, bp $100^{\circ} \mathrm{C} /$ $20 \mathrm{mmHg}$ のものを使用した。

\subsection{4 アジピン酸ジメチル (DMA)}

再結晶したアジピン酸を常法によりェステル化を行な い, 精留し bp $98 \sim 99^{\circ} \mathrm{C} / 10 \mathrm{mmHg}, n_{\mathrm{D}}^{30} 1.4246$ の留分 を使用した。

\subsection{5 メタノール}

市販一級メタノールを精留し, bp $64.5^{\circ} \mathrm{C}$ のものを使 用した。

\section{2 プレポリマーの合成}

MED 25 30 g を科取し，計算量の DMT を加え， 約 10 倍量のメタノールを加え, 還流冷却器を付して油 浴上で加熱還流を行ない, 均一な溶液にする。3 時間還 流後, $30 \mathrm{~cm}$ 長のウィドマー分留管を付し, かきまぜな がらメタノールを留去する。ほとんど留去してから浴温 を $150 \sim 160^{\circ} \mathrm{C}$ に昇温し, 析出物を溶融し, 残存するメ タノールを留去しながら 1 時間反応を続けると白色固形 物が得られる。放冷後, 減圧乾燥し粉砕した。得られた プレポリマーは白色でフェノールー四塩化ェタンの混合 溶媒中 $0.3 \%$ の還元粘度 $\left(\eta_{s p} / C\right)$ は $0.10 \sim 0.14$ であ った。これらの結果を Table 2 に示す。

比較のために HMD と DMA からも,全く同様の方
法でプレポリマーを合成した。アミノ末端の定量からプ レポリマーの数平均分子量は約 2000 程度である。重合 結果とともにまとめて Table 3 に示す。また, プレポ リマーの IR スペクトルを Fig. 1 に示す。

\section{3 重合法}

重合法は大別して減圧法, 常圧法, 加圧法の 3 法が考 えられる。この 3 法について検討を行なった。

\subsection{1 減圧重合法}

枝付き重合管にプレポリマー約 $5 \mathrm{~g}$ をとり, 乾燥窒素 ガスにて十分置換した後, $20 \mathrm{mmHg}$ で 1 時間, 次いで $2 \sim 3 \mathrm{mmHg}$ で所定時間溶融重縮合を行なった。加熱に はbp $283^{\circ} \mathrm{C}$ のジメチルフタレートの蒸気浴を用いた。

\subsection{2 常圧重合法}

減圧重合法と同じ装置を用い, 約 $5 \mathrm{~g}$ のプレポリマー をとり, 十分窒素ガスで㯰換した後，窒素ガスを通しな がら $283^{\circ} \mathrm{C}$ の蒸気浴を用いて重合を行なった。

\subsection{3 加圧重合法}

重合用試験管にプレポリマー $5 \mathrm{~g}$ を入れ, 水 $5 \mathrm{ml}$ を 加え，オートクレーブに入れ，十分窒素ガスで置換した 後, $260 \sim 270^{\circ} \mathrm{C}, 30 \mathrm{~kg} / \mathrm{cm}^{2}$ で 1.5 時間, つづいて同温 度に保ち， 0.5 時間かけて放圧し, $0 \mathrm{~kg} / \mathrm{cm}^{2}$ にし,さら に同温度で 3 時間重合を行なった。

\section{4 粘度测定}

MED-DMT 系はフェノールー四塩化ェタンの混合溶 媒(重量比 $60: 40$ ) を用い, 濃度 $0.3 \mathrm{~g} / 100 \mathrm{ml}$ でオスト 
Table 3. Preparations of prepolymers (HMD-DMA) and polymerization.

\begin{tabular}{|c|c|c|c|c|c|c|}
\hline \multirow{2}{*}{$\begin{array}{l}\text { Run } \\
\text { No. }\end{array}$} & \multirow{2}{*}{$\begin{array}{c}\text { Molar ratio } \\
\left(\mathrm{HMD}^{\mathrm{a})} /\right. \\
\left.\mathrm{DMA}^{\mathrm{b})}\right)\end{array}$} & \multicolumn{2}{|c|}{ Prepolymer } & \multicolumn{2}{|c|}{ Polymer } & \multirow{2}{*}{$\begin{array}{c}\text { Melt- } \\
\text { spinnability }\end{array}$} \\
\hline & & $\begin{array}{r}\left.\operatorname{mp}^{c}\right) \\
\left({ }^{\circ} \mathrm{C}\right)\end{array}$ & End group $\left[\mathrm{NH}_{2}\right]$ & $\underset{\left({ }^{\circ} \mathrm{C}\right)}{\mathrm{mp}^{\mathrm{c})}}$ & $\begin{array}{c}\eta_{s p} / C^{\mathrm{d})} \\
(C=0.3 \mathrm{~g} / 100 \mathrm{ml})\end{array}$ & \\
\hline $6 \mathrm{~N}-16$ & 0.95 & $227 \sim 238$ & 0.46 & $249 \sim 255$ & 0.70 & poor \\
\hline $6 \mathrm{~N}-17$ & 0.98 & $229 \sim 238$ & 0.42 & $249 \sim 256$ & 0.93 & good \\
\hline $6 \mathrm{~N}-18$ & 1.00 & $218 \sim 236$ & 0.48 & $249 \sim 255$ & 1.03 & good \\
\hline $6 \mathrm{~N}-19$ & 1.01 & $222 \sim 234$ & 0.49 & $250 \sim 256$ & 1.10 & good \\
\hline $6 \mathrm{~N}-20$ & 1.05 & $218 \sim 232$ & 0.55 & $248 \sim 256$ & 1.13 & poor \\
\hline $6 \mathrm{~N}-21$ & 1.10 & $218 \sim 230$ & 0.64 & - & 0.85 & no \\
\hline
\end{tabular}

a) HMD : Hexamethylene diamine,

c) measured by heating on a hot stage microscope,

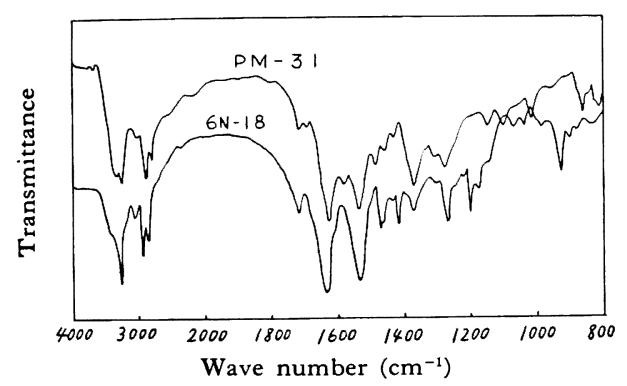

Fig. 1. Infrared spectra of prepolymer.

ワルド型粘度計にて $30^{\circ} \mathrm{C} て ゙$ 測定した。粘度はすべて還 元粘度 $\left(\eta_{s p} / C\right)$ で表わした。

HMD-DMA 系のポリマーは $m$-クレゾールを用い, 同濃度, 同温度で測定した。

\section{5 溶融紡糸}

窒素ガス押出式の $30 \sim 50 \mathrm{~g}$ 用の紡糸機を用いた。紡 糸条件は温度 $285^{\circ} \mathrm{C}$, 押出圧 $1.5 \mathrm{~kg} / \mathrm{cm}^{2}$ で挖取速度は $50 \sim 150 \mathrm{~m} / \mathrm{min}$, 延伸は沸水中で行なった。

\section{3. 実験結果および考察}

\subsection{MED/DMT モル比の検討}

ポリエステルの重合と同様に揮発性のジアミン成分を 過剩に用いた場合，アミド交換反応によって高重合度の ポリアミドが得られることを予期して，モル比の検討を 行なった。得られた結果を Fig. 2 に示す。

Fig. 2 から常圧法, 加圧法では過剩のジアミンは末端 停止効果を示すが，减圧法ではその効果は見られずアミ ン成分增加とともに粘度は上年し， $25 \%$ 過剩の 場合に はゲル化が著しくなり，溶剂に不溶となる。

比較のために酸成分が脂肪族で, 代表的なポリアミド であるポリへキサメチレンアジパミド（ナイロン 66）を HMD と DMA からプレポリマーを合成し,減圧重合を b) DMA : Dimethyl adipate,

d) measured in $m$-cresol at $30^{\circ} \mathrm{C}$

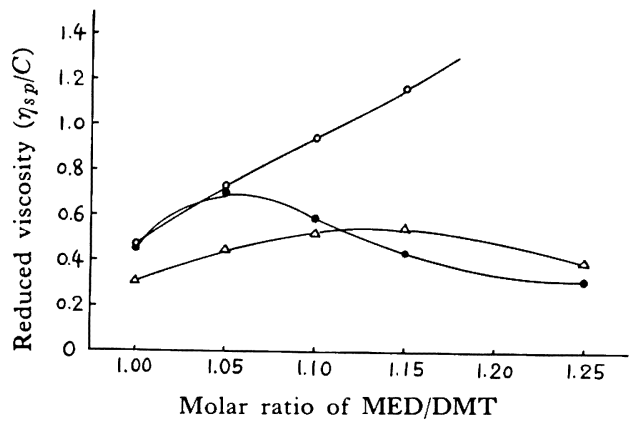

$\bigcirc$ : Polymerization under reduced pressure

- Polymerization at atomospheric pressure

$\triangle$ : Polymerization under pressure (in autoclave)

Fig. 2. Relation between molar ratio of $\mathrm{MED} / \mathrm{DMT}$ and solution viscosity of polyamide formed.

行ない, 同様にモル比の検討を行なった。結果は Table 3 に示した。 $6 \mathrm{~N}-21$ は著しく着色し, 明確な融点を示 さない。Fig. 2, および Table 3 の結果から MEDDMT 系と HMD-DMA 系では違った傾向を示す。 これは酸成分が芳香族と脂肪族に基く相違，すなわちア ミド化反応速度の差が現われていると考える。アミド化 反応速度の 小なる場合, プレポリマーの 分子量も低く, アミノ末端濃度が高く末端基どうしの反忍による第二級 アミンの生成に基く, 三次元化反応 ${ }^{8)}$ も考えられる。

以上の結果から, 高重合度のポリアミドを得るにはア ミン成分を過剩に用い, 重合には減圧工程が必要である。

\section{2 重合時間の検討}

常圧法や加圧法では高重合度のポリアミドが得られな いので以後, 減圧法をさらに検討した。

重合時間の影響を調べた結果を Fig. 3 に示す。重合 時間は $20 \mathrm{mmHg}$ で 1 時間とその後, つついて 2 $3 \mathrm{mmHg}$ での時間を加えた合計時間で表わした。

モル比 (MED/DMT) 1.00 および 1.05 の場合, 重 


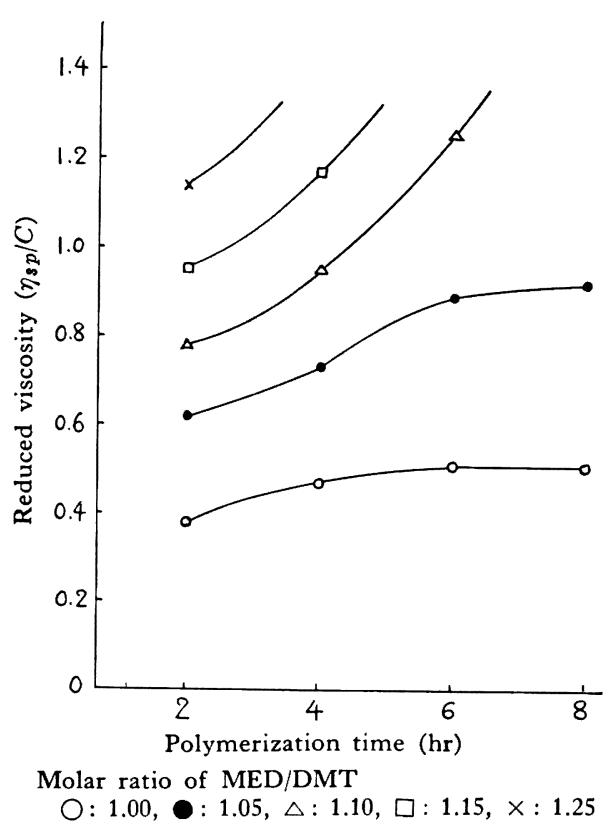

Fig. 3. Effects of molar ratio of MED/DMT on polyamide formation.

合時間を長くしても粘度の増加は少なく, 一定值に近つ き，良好なポリマーを与える。モル比 1.10 以上の場合 短時間ではゲル化しないが，重合時間が長くなるとゲル 化現象を示し溶剤に不溶となる。

以上の結果からゲル化とアミノ末端と密接な関係があ ることは明らかであるが，どのような機構で三次元化が 生するるか定かでない。さきに述べたように 2 個のアミノ 基から $\mathrm{NH}_{3}$ が除去されて第二級アミンが生成し，そこ に酸末端が反応して三次元化する場合と，アミド結合に
末端アミノ基が反応してアミジン結合が生成する場合が 考えられる。

\section{3 紡 糸}

Fig. 2 および Fig. 3 から可紡性良好なポリマーを得 るには, MED/DMT モル比 1.00〜1.05 の場合で重合 は減圧法が望ましいことがわかったので, 約 $30 \mathrm{~g}$ 重合 し，溶融紡系を行ない，系質を調べた。得られた結果の 一部を Table 4 および Table 5 に示す。

得られた繊維のヤング率はナイロン 6 の $150 \sim 300 \mathrm{~kg} /$ $\mathrm{mm}^{2}(14.5 \sim 29.2 \mathrm{~g} / \mathrm{d})$ に比し, 相当高い值を示しており また, ポリェチレンテレフタレートの $400 \sim 1000 \mathrm{~kg} /$ $\mathrm{mm}^{2}(32.2 \sim 80.5 \mathrm{~g} / \mathrm{d})$ に近い值を示している。

\section{4 ポリマーの溶解性}

MED と DMT から得られたポリアミドの溶解性を 他のポリマーと比較して Table 6 に示す。

MED-T ポリアミドは溶解性の点においてもナイロン 6 とポリェチレンテレフタレートの中間の性質を示す。

\section{4. 結言}

エチレンと塩化シアンのテロメリゼーション反応によ り生成するテロマーの誘導体である脂肪族混合ジアミン (MED) と, テレフタル酸ジメチル (DMT) とからプレ ポリマーを経由して, $\mathrm{mp} 225 \sim 235^{\circ} \mathrm{C}$ の溶融紡系可能 な共重合ポリアミドを得た。

重合法では，減圧法が最もよい結果を得た。MED/ DMT モル比 1.00 1.05 では重合時間の長短にかかわ らず良好なポリマーが得られ，重合時間 6 時間で粘度は 一定值に近づくが，モル比 1.10 以上ではアミン成分の 増加とともに短時間でゲル化したポリマーを与える。减 圧重合法においてはアミノ末端は末端停止効果なく, 三 次元化の原因となる。

簡単な溶融紡系によって得られた繊維のヤング率は,

Table 4. Polymerization of prepolymer (MED-DMT).

\begin{tabular}{|c|c|c|c|c|c|c|c|}
\hline \multirow{2}{*}{$\begin{array}{l}\text { Expt. } \\
\text { No. }\end{array}$} & \multirow{2}{*}{$\begin{array}{l}\text { MED } \\
\text { No. }\end{array}$} & \multirow{2}{*}{$\begin{array}{c}\text { Molar ratio } \\
\text { (MED/DMT) }\end{array}$} & \multicolumn{3}{|c|}{ Polymerization condition } & \multirow{2}{*}{$\begin{array}{l}\mathrm{mp} \\
\left({ }^{\circ} \mathrm{C}\right)\end{array}$} & \multirow{2}{*}{$\begin{array}{l}\text { Reduced } \\
\text { viscosity } \\
\left(\eta_{s p} / C\right)^{\mathrm{b})}\end{array}$} \\
\hline & & & $\begin{array}{c}\text { Temperature } \\
\left({ }^{\circ} \mathrm{C}\right)\end{array}$ & $\begin{array}{l}\text { Pressure } \\
(\mathrm{mmHg})\end{array}$ & $\begin{array}{l}\text { Time } \\
(\mathrm{hr})\end{array}$ & & \\
\hline$P-55$ & D-24 & 1.02 & 283 & $\begin{array}{r}760 \\
20 \\
2 \sim 3\end{array}$ & $\begin{array}{l}0.5 \\
1.0 \\
2.5\end{array}$ & $225 \sim 236$ & 0.78 \\
\hline$P-62$ & D-36 & 1.05 & 283 & $\begin{array}{r}20 \\
2 \sim 3\end{array}$ & $\begin{array}{l}1.0 \\
4.0\end{array}$ & $228 \sim 235$ & 0.89 \\
\hline$P-64$ & $D-36$ & 1.05 & 283 & $\begin{array}{r}20 \\
2 \sim 3\end{array}$ & $\begin{array}{l}1.0 \\
4.0\end{array}$ & $222 \sim 231$ & 0.85 \\
\hline
\end{tabular}

a) using vapor bath of dimethyl phthalate (bp $283^{\circ} \mathrm{C}$ )

b) measured at concentration of $0.3 \mathrm{~g} / 100 \mathrm{ml}$ of phenol-tetrachloroethane $(6: 4)$ and at $30^{\circ} \mathrm{C}$ 
Table 5. Properties of MED-T fiber.

\begin{tabular}{c|c|c|c|c|c}
\hline \hline $\begin{array}{c}\text { Expt. } \\
\text { No. }\end{array}$ & $\begin{array}{c}\text { Polymer } \\
\text { No. }\end{array}$ & $\begin{array}{c}\text { Denier } \\
(\mathrm{d})\end{array}$ & $\begin{array}{c}\text { Dry strength } \\
(\mathrm{g} / \mathrm{d})\end{array}$ & $\begin{array}{c}\text { Dry elongation } \\
(\%)\end{array}$ & $\begin{array}{c}\text { Young modulus } \\
(\mathrm{g} / \mathrm{d})\end{array}$ \\
\hline SP-1 & P-55 & 12.6 & 2.29 & 26.4 & - \\
SP-7 & P-62 & 19.6 & 2.68 & 39.4 & - \\
SP-8-2 & P-64 & 17.6 & 2.89 & 26.1 & 47.7 \\
SP-8-3 & P-64 & 34.0 & 2.77 & 36.0 & 45.4 \\
\hline
\end{tabular}

Table 6. Solubilities of polymers in various solvents.

\begin{tabular}{|c|c|c|c|}
\hline Solvent & MED-T Polyamide & Polycapramide (Nylon 6) & Poly(ethyleneterephthalate) \\
\hline$m$-Cresol & m & m & H \\
\hline Concentrated sulfuric acid & m & m & m \\
\hline $85 \%$ Formic acid & + & m & - \\
\hline Phenol-tetrachloroethane $(60: 40)$ & m & m & m \\
\hline Benzyl alcohol & + & + & + \\
\hline Dimethyl formamide & + & + & $\mp$ \\
\hline Nitrobenzene & + & + & + \\
\hline$o$-Dichlorobenzene & - & - & $\mp$ \\
\hline
\end{tabular}

-: Unaffected by hot solvent,

+ : Soluble in hot solvent, precipitated cold, H: Soluble in hot solvent, remains soluble cold,

Ht: Soluble in cold solvent

主鎖中に $p$-フェニレン核を有するためポチェチレンテ レフタレートのそれに近い値を示した。また，ポリマー の溶解性もナイロン 6 とポリエチレンテレフタレートの 中間を示した。

付 記：昭和 39 年 11 月, 第 10 回学協連秋季研究発表大会 (中大)で報告した。なお, 試料の脂肪族混合ジアミンを提供し て下さった日本曹達株式会社に深謝する。さらに, 本研究の発 表を許可された当社纎維技術研究所長森本佐一取楴役, ならび に研究のご指導をいただいた研究室長山本晃博士，また，種々 ご教示いただいた和田実, 三輪慎治両氏に深謝する。

\section{文献}

1) J. A. Somers: Brit. Rayon \& Silk J., 26, 64 (1950)
2) 岩倉義男： 合成繊維討論会 (1956 年 11 月 7日, 大 阪)

3) USP 2766221 (1956)

4) BP $825096(1959)$

5）岡 太昭ほか：有合化協誌，16，252，255，360, $416,458(1958) ; 17,607,766(1959)$

6) 和田 実, 三輪慎治, 後藤芳弘, 竹内芳文, 進藤昭 次：第 10 回学協連秋季研究発表大会(1964 年 11 月 15 日, 東京)

7) 秋吉三郎, 橋本静信, 高見和秀, 岡村陸彦: 工化, 57, $212(1954)$

8） Rolland Hill (小方芳郎, 井上正一訳)：「合成纎維」 105 (丸善)

\section{Synthesis of Polyamide Having Aromatic Rings in the Main Chain}

I. Study of Polymerization Conditions of Dimethyl Terephthalate and Mixed Aliphatic Diamines

\section{By Yoshihiro Goto*}

New polyamide was prepared by the polycondensation of prepolymer obtained in methanol by the reaction of dimethyl terephthalate and mixed aliphatic diamines, which were derived from

* Textile Research Institute, Toyo Spinning Co., Ltd. (Katata, Shiga)

Present address: Inuyama Plant, Toyo Spinning Co. Ltd. (Kotsu, Inuyama, Aichi) 
the telomers of ethylene and cyanogen chloride. This polyamide melted at $225 \sim 235^{\circ} \mathrm{C}$.

Polymerization conditions were investigated to get a polymer having a good melt-spinnability.

Solubility of this polymer lay between that of polycapramide (Nylon 6) and poly (ethylene terephthalate), and Young's modulus of the fiber obtained from melt-spinning was higher than that of polycapramide as it was expected.

\title{
第 2 報 ポリアミドの融点降下について
}

(1965 年 9 月 20 日受理)

後藤芳弘* ・遠藤誠司**

\begin{abstract}
要旨 テレフタル酸ジメチルの脂肪族混合ジアミンによるアミノリシス反応で生成するポリアミドの 融点は, 同一構造を有すると考えられるナイロン塩経由のポリアミドの融点よりも約 $20 \sim 25^{\circ} \mathrm{C}$ 低、值を示 す。この融点降下について検討した結果, プレポリマー生成時のアミノリシス反応速度が小さいため, 副反応 が起こり, 第二級アミンが生成し，ポリマー中に導入され， N-メチルアミド結合となり，融点を降下させるこ とがわかった。テレフタル酸ジメチルよりはるかに反応性に富むテレフタル酸ジフェニルを用いると, プレポ リマー中に第二級アミンは存在せず, 分子量の大きいものが 得られる。したがって，N-メチル化のない融点 $245 \sim 258^{\circ} \mathrm{C}$ の良好なポリマーが得られた。
\end{abstract}

\section{1. 緒言}

エチレンと塩化シアンのテロメリゼーション反応によ り得られるテロマーの誘導体である脂肪族混合ジアミン (以下 MED と略す) と, テレフタル酸ジメチル (以下 DMT と略す) とから融点 $225 \sim 235^{\circ} \mathrm{C}$ の可紡性で, 冷 延伸可能なポリアミドが得られることを報告した ${ }^{1)}$ が, MED とテレフタル酸とからナイロン塩を経由して合成 したポリアミド2)に比して同一組成にもかかわらず，ポ リマーの融点が約 $20 \sim 25^{\circ} \mathrm{C}$ と低い值を示す。また, 溶 融紡系によって得られた繊維の強度も粘度が高いにもか かわらず低い值を示す。

本報告では重合法の相違が，ポリマーの融点に及ぼす 効果について検討した。

\section{2. 実験}

\section{1 試 料}

\section{1 .1 脂肪族混合ジアミン (MED)}

合成工程および分析法については前報 ${ }^{1)}$ で述べた。本 報で用いた MED の分析值を Table 1 に示す。

\subsection{2 テレフタル酸ジフェニル}

テレフタル酸ジクロライドより B. H. Chase ${ }^{3)}$ の方法 に従い, 合成し, クロロホルムより 2 回再結晶し, mp $198 \sim 199^{\circ} \mathrm{C}$ のものを使用した。

* 東洋紡績株式会社絨維技術研究所（滋賀県 滋賀郡堅田町本 堅田)

現在：東洋紡績株式会社犬山工場 (愛知県犬山市大字木津)

** 東洋紡績株式会社繊維技術研究所（滋賀県 滋賀郡堅田町本 堅田)
Table 1. Analysis of MED.

\begin{tabular}{c|c|c|c}
\hline $\begin{array}{c}\text { MED } \\
\text { No. }\end{array}$ & $\begin{array}{c}\text { Total amine } \\
\text { (milli eq./g) }\end{array}$ & $\begin{array}{c}\text { Average } \\
\text { molecular weight }\end{array}$ & $\begin{array}{c}\text { Average } \\
(2 n+2)\end{array}$ \\
\hline D-22 & 13.22 & 151.28 & 8.53 \\
D-42 & 12.62 & 158.48 & 9.01 \\
D-47 & 12.61 & 158.64 & 9.02 \\
\hline
\end{tabular}

\subsection{3 ベンゼン}

市販一級品を濃硫酸で洗浄し, 金属ナトリウムで乾燥 後, 精留し, bp 79.5 80 C のものを用いた。

\subsection{4 ジオキサン}

市販一級品を 金属ナトリウムで乾燥した後, 精留し, bp $101^{\circ} \mathrm{C}$ のものを用いた。テレフタル酸ジメチル,メ タノールについては，既述”した。

\section{2 プレポリマーの末端基の定量}

\subsection{1 全アミンの定量}

減圧下で乾燥させたプレポリマー約 $0.5 \mathrm{~g}$ を精秤し, $100 \mathrm{ml}$ のビーカーにとり, $88 \%$ フェノール水溶液 $40 \mathrm{ml}$ を加え完全に溶解させ, さらにェタノール $5 \mathrm{ml}$ と水 $5 \mathrm{ml}$ を加え, $N / 2-\mathrm{HCl}$ 標準溶液にて電位差滴定を行な った。

\subsection{2 第二級アミンの定量4)}

乾燥したプレポリマー約 $0.5 \mathrm{~g}$ を精科し, $90 \%$ フェ ノールのメタノール溶液 $60 \mathrm{~m} l$ に完全に溶解させ, 市販 特級サルチルアルデヒド $5 \mathrm{ml}$ を加え, 室温で 30 分間 かきまぜを行ない， $N / 2-\mathrm{HCl}$ 標準溶液をミクロビュー レットより滴下し, 電導度滴定を行なった。サルチルア ルデヒドを加えると第一級アミンはシッフ塩基となり, 